\title{
Role-Playing Game as Learning Media To Support Online Learning
}

\author{
Vinza Hedi Satria ${ }^{1 *}$, Darlis Herumurti ${ }^{2}$ (D) \\ 1,2 Prodi Teknik Informatika, Institut Teknologi Sepuluh Nopember, Jawa Timur, Indonesia
}

\section{A R T I C L E I N F O}

Article history:

Received September 29, 2021

Revised September 30, 2021

Accepted October 12, 2021

Available online November 25, 2021

Kata Kunci:

Media Pembelajaran, Role-Playing Game, Pembelajaran Online

Keywords:

Learning Media, Role-Playing Game, Online Learning

DOI:

https://dx.doi.org/10.23887/jet.v5i4.39 718

\begin{abstract}
A B S T RA K
Kurangnya media pembelajaran akan mempengaruhi proses pembelajaran di kelas. Media pembelajaran yang bervariasi mampu memotivasi murid dalam aktivitas pembelajaran online. Hal ini yang menyebabkan media pembelajaran sangat penting dalam proses pembelajaran. Di era pembelajaran online saat ini, murid rentan terhadap rasa bosan dan stress, oleh karena itu peneitian ini bertujuan untuk mengembangkan media pembelajaran bertema RPG (Role Playing Games) dan melihat dampaknya kepada. Penelitian ini bersifat eksploratori dikarenakan field dari game yang sangat luas dengan di validasi menggunakan survey E-GameFlow untuk menilai tingkat kenyamanan pemain saat mendapatkan ilmu pengetahuan. Penelitian akan dilakukan kepada 15 siswa SMP dengan menyebarkan kuisioner secara online. Metode yang digunakan untuk mengumpulkan data yaitu observasi dan kuesioner. Instrument yang digunakan untuk mengumpulkan data yaitu kuesioner. Teknik yang digunakan untuk menganalisis data yaitu analysis deskriptif kualitatif dan kuantitatif. Hasil dari masing-masing pertanyaan pada tiap aspek EGameFlow akan dianalisis untuk menemukan kesimpulan mengenai game yang telah dibuat. Melalui hasil data yang didapatkan, nilai terendah adalah 5.49 pada aspek tantangan (challenge) yang salah satunya disebabkan oleh peta permainan yang statik dan kurangnya panduan mengenai permainan. Hasil keseluruhan dari E-GameFlow menunjukkan bahwa game mampu memberikan kenyamanan kepada pemain saat dalam proses pemberian materi pembelajaran, hal ini terbukti dari tidak ada aspek dengan nilai dibawah ratarata.
\end{abstract}

\begin{abstract}
A B S T R A C T
Lack of learning media will affect the learning process in the classroom. Various learning media can motivate students in online learning activities. It causes learning media to be essential in the learning process. In the current era of online learning, students are prone to boredom and stress. Therefore this study aims to develop learning media with RPG (Role Playing Games). This research is exploratory because the field of play is vast, with validation using an E-GameFlow survey to assess the level of comfort of players when gaining knowledge. The research will be conducted on 15 junior high school students by distributing online questionnaires. The methods used to collect data are observation and questionnaires. The instrument used to collect data is a questionnaire. The technique used to analyze the data is descriptive qualitative and quantitative analysis. The results of each question on each aspect of E-GameFlow will be analyzed to find conclusions about the games that have been made. The results of the data obtained show that the lowest value is 5.49 in the challenge aspect, which is caused by a static game map and lack of guidance regarding the game. The overall results of E-GameFlow show that the game can provide comfort to players while providing learning materials. This is evident from no aspect with a score below the average.
\end{abstract}

This is an open access article under the CC BY-SA license. Copyright $(C) 2021$ by Author. Published by Universitas Pendidikan Ganesha.

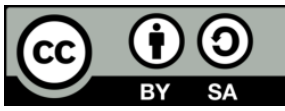

\section{INTRODUCTION}

In the current era of online learning, the academic community must make adjustments both in terms of how to teach teachers and how to receive teaching for students (Akyol \& Garrison, 2011; Binali et al., 2021; Yulia, 2020). A survey conducted by research reveals several things that become obstacles in online learning, including an unstable network, piling tasks and limited quotas (Mufaziah \& Fauziah, 2020; Rigianti, 2020; Windhiyana, 2020). The problems experienced by the academic community cannot be taken lightly, because the survey also stated that almost sixty percent of participants felt that the problems that occurred from online learning were quite disturbing (Buchori et al., 2017; E. Chen \& Li, 2011; Nonthamand, 2020). Therefore other learning media besides online using web conferencing applications were needed to assist the learning process. 
The development of learning media able to make students to grow learning motivation, the meaning of teaching materials will be clearer and students will not be bored (Dinayusadewi et al., 2020; Rahayuningsih, 2020). Learning media also has great potential to attract the attention of participants to participate and create creative communication (Kucker, 2021; Prasetyo et al., 2020). Motivation in education is what not just the student but also teacher need, moreover in this era of pandemy where the Ministry of Education, Culture, Research and Technology of Indonesia once said, long term online learning put more stress for the student (Abidah et al., 2020; Anitha Kumari et al., 2020). Creating different learning media that able to increase the learning motivation become more critical than ever (Buchori et al., 2017; Nonthamand, 2020; Rahayuningsih, 2020). Choosing learning media is another problem, research for this topic has been done previously. Research conducted a mapping of various kinds of learning media used by a franchise "Cells at Work!" Among them there are learning media for comics, games, websites, songs, and animations that has been used for the francise, among them game as learning media for "Cells at Work!" are considered unsucessful, the reason were mentioned in the research where the development of the games for the francise are lacking, thus making the game less attractive and didn't fully utilize the benefit of game as learning media, which raise a question, how much is the effectiveness of game as learning media? (Cintya et al., 2021).

Making games as learning media need to take attention in the game genres, different genre can distinguish the way in how learning material is delivered (Su \& Cheng, 2013; Wulandari et al., 2017). Several genres have been studied for their effectiveness in a field, to examine the effectiveness level of the puzzle, RPG and puzzle-RPG genres in conveying mathematical material, through this research it was revealed that puzzle-RPG provided the highest increase in learning outcomes, while RPG is in second place and puzzle is in last place (Hermawan et al., 2017). There are various research on using game as learning media, but the number of unresearched field remain at large since there are various gamification technique and educational material that affect the whole research (Elianta et al., 2018; Herdiansyah et al., 2019; Rekysika \& Haryanto, 2019).

The research create pseduo-code like quiz game where the game gave user a consol-like interface and ask user to solve simple programming problem by doing some coding activities, this research evaluated using usability survey with passable result (Mathew et al., 2019). The research create puzzle game to decide step that the player must take in order to reach certain goals, this game teach it's user the basic programming concept such as looping, if/else condition and using TAM ( Technology Acceptance Model) as it's evaluation method (Giannakoulas \& Xinogalos, 2018). Create game that teach cybersecurity based on pretty famous game model, the Dungeon and Dragon and using performance test as it's main evaluation method and a survey (Kido et al., 2020). Create adventure platformer game to teach geometry, however this research did not use any evaluation method (Kartika et al., 2018). Research create Fighting-based game with grammar quiz as it's weapon and using usability test as evaluation method (Yunanto et al., 2019). There are more research in educational game than what already mentioned above, however there still more untouched field remain as the genre of game still grew large, but the variety of genre itself need to be tested it's effectiveness in delivering learning material. Thus an exploratory research will be conducted to further explore how effective a game as learning media. Research will design a game with an RPG as it's main theme, even if research conducted by (Hermawan et al., 2017). The RPG were second to the puzzle RPG in term of effectiveness, the genre RPG is one of the most favorable genre in the gaming market (Hergenrather, 2020). The educational material to be raised will be from first grade junior high school material.

\section{METHOD}

The research to be carried out is divided into three processes, the first process is the selection of junior high school material to be gamified so that it can be implemented into the game, the next process is game design and the last process is evaluating the influence of the designed game. The procedure of our research can be seen in figure 1 below.

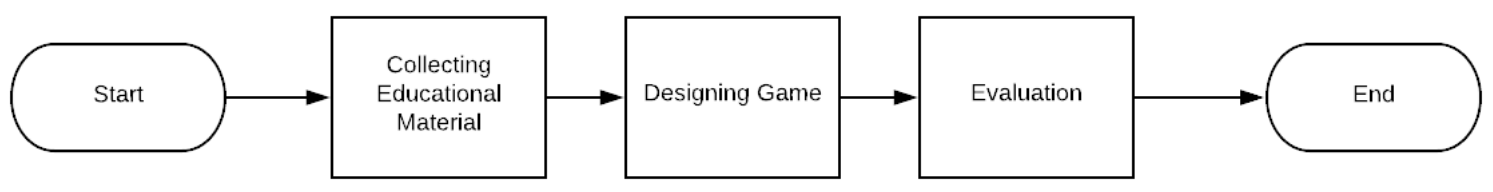

Figure 1. Research Procedures

First step of the research will be collecting educational material, this step will be done by doing literature review from certain source, including Revised K-13 Indonesian's Curriculum. Next step the 
designing process for the game will begin, beside creating a playable game, gamification proses also done in this process, raw text-based material that already collected from previous step will be integrated element inside the game. Last step will be evaluation process, in the evaluation process we gave online questionnaire to user after done playing game that has been designed from previo step, user will have to answer few question based on E-GameFlow's questionnaire. For the further detail can be seen below. Due to the broad material not all of it can be gamified, in this study, first we conduict literature review on Revised K-13 curriculum, then several Mathematics and Natural Sciences materials were taken based on the Basic Competencies of the Revised K-13 curriculum. The material that will be processed into gamification is in table I below.

Table 1 Research Procedures

\begin{tabular}{|c|c|c|}
\hline Subject & K.D & Materi \\
\hline IPA & 3.3 & $\begin{array}{l}\text { Explain the concept of mixtures and single substances (elements and compounds), physical } \\
\text { and chemical properties, physical and chemical changes in everyday life }\end{array}$ \\
\hline Matematika & 3.1 & Explain and determine the order of integers \\
\hline Matematika & 3.2 & $\begin{array}{l}\text { Explain and perform arithmetic operations on integers and fractions by utilizing various } \\
\text { properties of operations }\end{array}$ \\
\hline Matematika & 3.3 & $\begin{array}{l}\text { Explain and determine the representation of numbers in the form of positive and negative } \\
\text { integers }\end{array}$ \\
\hline Matematika & 3.4 & $\begin{array}{l}\text { Explain sets, subsets, universal sets, empty sets, complement sets, and perform binary } \\
\text { operations on sets using contextual problems }\end{array}$ \\
\hline
\end{tabular}

Based on mentioned educational material above, then we conduct second literature review to collect question database based on agreed educational material. After collecting educational material, designing the game's system is conducuted. The map in the game will be static, this action was taken so map combination will not affect the results of the evaluation of the educational elements of the game. To assess the impact of the designed games, an online survey using googleform was conducted on the level of satisfaction of players when playing educational games after players finished playing the game. The participants were 15(Fifteen) 7th grade junior high school students, due to the distribution of the survey conducted online using googleform, the study did not limit the origin of the junior high school students from the participants but all students domiciled in Surabaya, Indonesia. The survey questionnaire was distributed online using Educational Game Flow based. The list of questions in E-GameFlow was modified in several parts to suit the research carried out, while the modifications made were: Deleting the question category "Social Interaction" this was done because the game developed was a single player game so it did not have aspects To this, two other questions were added, namely the origin of the junior high school from the participants and the participant's experience in the game world (casual or experience) which served as considerations for the final analysis. The full question list based on EGameFlow can be seen in Table below.

Table 2. E-GameFlow Question List (Fu, Su, \& Yu, 2009)

\begin{tabular}{ll}
\hline Aspect & Question \\
\hline Concentration & The game grab my attention \\
The game provide content that stimulate my attention \\
Most of gaming activities are related to the learning task \\
No distraction from the task is highlighted \\
Generally speaking, I can remain concentrated in game \\
I am not distracted from task that the player should concentrate on \\
I am not burdened with task that seem unrelated \\
Workload in the game is adequate \\
Overall game goals were presented in the beginning of game \\
Overall game goals were presented clearly \\
Intermediate goals were presented in the beginning of each scene \\
Intermediate goals were presented clearly \\
I understand the learning goals through the game \\
I receive feedback on my progress in game \\
I receive immediate feedback on my actions \\
I am notified of new tasks immediately \\
I am notified of new event immediately \\
I receive information on my success (or failure) of intermediate goals immediately \\
I receive information on my status, such as score or level
\end{tabular}




\begin{tabular}{|c|c|}
\hline Aspect & Question \\
\hline \multirow[t]{10}{*}{ Challenge } & I enjoy the game without feeling bored or anxious \\
\hline & The challenge is adequate, neither too difficult or too easy \\
\hline & The game provide 'hints' in text that help to overcome the challenge \\
\hline & The game provide 'online support' that help to overcome the challenge \\
\hline & The game provide video or audio that help to overcome the challenge \\
\hline & My skill gradually improves through the course of overcoming challenge \\
\hline & I am encouraged by the improvement of my skills \\
\hline & The difficulty of challenge increase as my skills improved \\
\hline & The game provide new challenges with an appropiate pacing \\
\hline & The game provide different levels of challenges that tailor to different players \\
\hline \multirow[t]{9}{*}{ Autonomy } & I feel sense of control the menu \\
\hline & I feel sense of control over action of role or object \\
\hline & I feel a sense of control over interactions between role or object \\
\hline & $\begin{array}{l}\text { The game doesn't allow player to make error to a degree that they cannot progress in } \\
\text { the game }\end{array}$ \\
\hline & The game support my recovery from fatal error \\
\hline & I feel that I can use strategies freely \\
\hline & I feel sense of control impact the game \\
\hline & I know next step of the game \\
\hline & I feel a sense of control over thegame \\
\hline \multirow[t]{8}{*}{ Immersion } & I forget about time passing while playing the game \\
\hline & I become unaware of my surrounding while playing the game \\
\hline & I temporarily forget worries about everyday life while playing the game \\
\hline & I experience an altered sense of time \\
\hline & I can become involved in the game \\
\hline & I feel emotionally involved in the game \\
\hline & I feel viscerally involved in the game \\
\hline & The game increase my knowledge \\
\hline Knowledge & I catch the basic idea of the knowledge taught \\
\hline \multirow[t]{3}{*}{ Improvement } & I try to apply the knowledge in the game \\
\hline & The game motivates me to integrate the knowledge taught \\
\hline & I want to know more about the knowledge taught \\
\hline
\end{tabular}

The game will be distributed online, then participants are invited to play the game, there is no time limit on the length of time the participant plays the game but the participant must complete the game in one play, after the game is successfully completed by the participant, the game will take the participant to the google form survey page where the participant fill out a survey. The survey results obtained will be analyzed using data processing tools such as Microsoft Excel. To understand better about score from each aspect, analysis on each question will be done. After the survey has been collected, this data will be represented using Microsoft Excel based on its aspect in E-GameFlow. Score from each aspect then ranked from highest to lowest to find out aspect that superior and become a drawback for current research. After rank of aspect has been formed, each question from each aspect are analyzed to understand the exact problem that become a drawback to be fixed in future research or strong point that need to be maintaned in the future.

\section{RESULT AND DISCUSSION}

\section{Result}

First, an educational gamification model is created based on educational material that has been collected, there are three forms of gamification made in the designed game. The first gamification is for science subjects at K.D 3.3 where gamification was created to explain changes in the shape of objects, in this study, we used changes in the form of water which can change into three forms of objects, namely liquid, solid and gas. The second gamification is a Quiz for mathematics subjects K.D 3.1 - 3.4 which is formed into a temple building quiz, where players choose a stone block containing the correct answer to build a temple in Figure 4 above. 


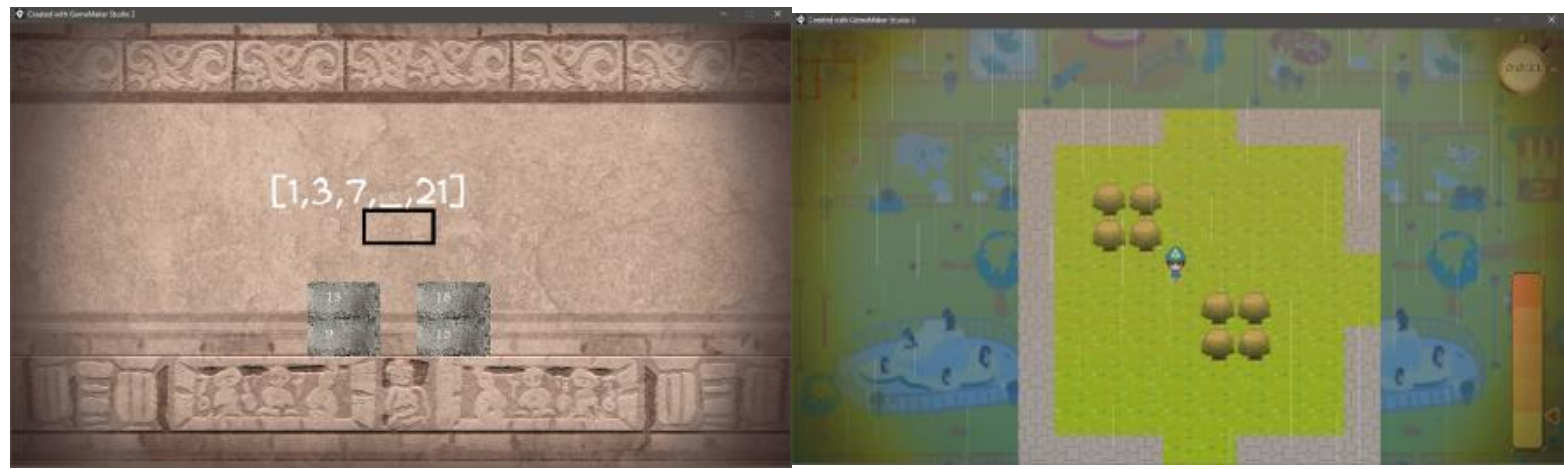

Figure 2. Adventure screen

In addition to the education material that has been described, the designed game also offers adventure in dungeons like RPG games in general, this will be the main idea of the game, as shown in Figure 2, the game will have twelve rooms, each room has different contents, where room $\mathrm{S}$ is where the player starts the game, room $\mathrm{E}$ is an empty place, while room I is where players get help in the form of additional lives, and $\mathrm{K}$ is related to $\mathrm{G}$. Room K, abbreviation of Key able to open the existing blockade on G, the Gate, $\mathrm{O}$ is where the enemy is and finally $\mathrm{F}$ is the finish, the goal of the player. When you get to the finish, players will then be given questions in the form of a quiz in figure 4 that must be answered 5 times. in dungeons, players will encounter challenges and items that can be utilized as shown in Figure 5 where player able to hide behind small tree to decrease the chance of encountering new enemy. Next, the result from evaluation phase will be explained through a survey that has been conducted to fifteen respondents using the E-Gameflow questionnaire which has been translated into Indonesian, the results are presented in the form of a bar graph in Figure 2.

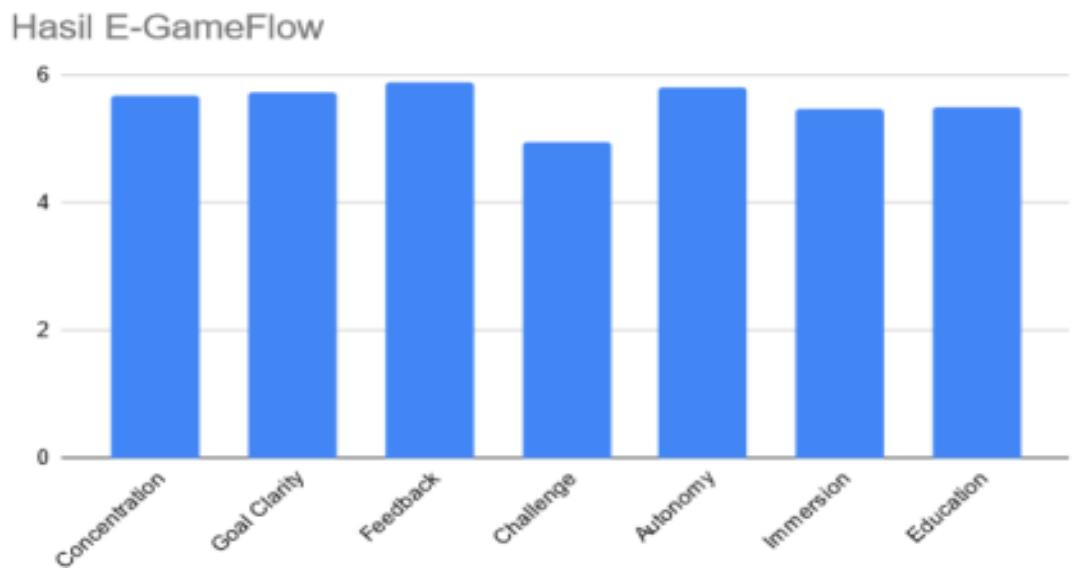

Figure 2. E-Game Flow Average Score

Based on figure 6 , the lowest score will be at challenge aspect while the highest aspect will be feedback and autonomy, to understand what this result mean an analysis conducted based on score for each question in every aspect.

\section{Discussion}

The game that has been designed has shortcomings in the challenge aspect, this is evidenced by the survey results which state that the challenge aspect is at a value of 4.96, although it is still above the average, but this value is the lowest value among other aspects. May help to answer this problem, this is could be due to the static map shape, making players feel bored when playing the game repeatedly, where a dynamic map could help the player to feel less bored since it could change the gameplay experience (Constant \& Levieux, 2019; Greipl et al., 2020; Partovi \& Razavi, 2019). Other problems arise because the games designed are not accompanied by outside assistance such as video tutorials or other assistance on websites that explain the game mechanics while the E-Gameflow's question itself asks for the mentioned assitance above, however these are aspects beyond the purpose of the study, namely making an educational game, but it is possible to add it in the future research. The highest aspects are feedback and autonomy with a score of 5.9 and 5.825. In feedback, the game provides players with clarity on the objectives of the mission by providing a pop-up display of ongoing missions and new 
missions that are open, besides that the game also provides commensurate feedback from the player's efforts against enemies in the form of several rewards such as money for every success defeat the enemy (Gustiana \& Puspita, 2020; Troussas et al., 2020).

In autonomy, the player has the personal right to play the game as he wishes in the fight, the player can choose several strategies such as whether to exploit the enemy's shape change, attack until the enemy loses, or even the player wants to repel the enemy without defeating him by taking advantage of the conditions provided by the player, like weather conditions, with this various strategy, player able to reflect on what they do and don't (Kusuma et al., 2021; Simbolon \& Satria, 2016). Increasing the autonomy that the game had. Concentration, Goal Clarity, Immersion are at the middle level, namely 5.67, 5.74 and 5.48. Concentration on the game can be obtained by players if the game is considered by the player to attract attention and is not too burdened by side missions (Kim et al., 2012; Sun \& Gao, 2016). In the designed game, there is a side quest that can be completed while following the flow of the main mission, therefore side missions do not interfere player concentration (Emerson et al., 2020; Yeh et al., 2017). Concentration and Challenge aspect can be improved further by designing missions that are appealing to the player but still don't overwhelm the player according to the difficulty curve where flow of the game remain between difficult and easy (Herdiansyah et al., 2019; Saprudin et al., 2019). In goal clarity, the goal of the game is clear, namely to get out of the dungeon that has been created, besides that, along with the Feedback aspect, a mission notification will appear to clarify the purpose of the game.

The Knowledge Improvement aspect which is the most important aspect in the research carried out has a value of 5.49 and includes the three lowest of all aspects after Immersion and challenge, based on the opinions that have been given by respondents, several points that can improve the value of the Knowledge Improvement aspect were found, including: The appearance of the designed quiz is not pleasant so it makes the process of working on the questions uncomfortable and make player feel bored (Lauc et al., 2020; Setiyani et al., 2020; Van Alten et al., 2019). Another problem is that the game is not able to make the player implement the knowledge he has got, the question has the answer with the lowest score, where most of the respondents who have played the game do not want to implement the knowledge that has been obtained from the game. This may happen because the knowledge is conveyed in a way that is less attractive, thus making players feel a bit bored, this is supported by other questions on knowledge improvement such as wanting to know the knowledge more knowledgeable also get a lower score. In other questions, such as the player's understanding of the educational element of the game, the score tends to be higher, this shows that the player understands the knowledge given.

Adding an educational element to cover more material. The addition of material also requires other gamification designs that are relevant to the mentioned material itself, it is also possible to include educational elements into the story elements, if this action was taken, the game will not only get additional education material but also be able to increase student's motivation in learning (All et al., 2021; Li et al., 2021; Pratama \& Setyaningrum, 2018). In the game, some UI and graphic designs need to be updated, especially in the font selection section and character sprites. The visual appeal and powerful feedback of game that make the game itself become "Juicy" can contribute to the success of the game to attract user (Agung et al., 2019; Y.-L. Chen \& $\mathrm{Hsu}, 2020)$. In the game, adding a guide outside and inside the game that serves to give players more information about the game can be done. Adding tutorial missions at the beginning of the game able to help players to get to know the game's mechanism. Beside from the game itself, adding guides from another media such as PDF books that are shared online or in the form of videos that are shared using video portals also help the player to understand the game further. In order to improve the Challenge aspect, Dynamic Difficulties Adjustment elements can be added so that players are able to experience a more varied level of difficulty and provide different challenges in each game, giving player different experience and become less bored from every gameplay (Bartel \& Hagel, 2014; Troussas et al., 2020).

\section{CONCLUSION}

Through the research that has been done, it produces an educational game with an RPG theme and answers RQ 1. For RQ 2, it can be answered based on the evaluation that has been done by using the EGameflow questionnaire, it can be stated that the game that has been created able to make players feel comfortable while playing the designed educational game, this can be proofed by none of the aspects of EGameflow that have a value less than four which is a neutral value for the questionnaire. This research conclude that RPG theme game have mediocore aspect in player's effectiveness in receiving learning material in math problem.

\section{REFERENCES}

Abidah, A., Hidaayatullaah, H. N., Simamora, R. M., Fehabutar, D., \& Mutakinati, L. (2020). The Impact of 
Covid-19 to Indonesian Education and Its Relation to the Philosophy of "Merdeka Belajar." Studies in Philosophy of Science and Education, 1(1), 38-49. https://doi.org/10.46627/sipose.v1i1.9.

Agung, Guna, \& Pudjawan. (2019). Game Education Mata Pelajaran Matematika Untuk Siswa Kelas IV SD Negeri 1 Paket. Jurnal Edutech Undiksha, 7(2), 2019. https://doi.org/10.23887/jeu.v7i2.21669.

Akyol, Z., \& Garrison, D. R. (2011). Understanding cognitive presence in an online and blended community of inquiry: Assessing outcomes and processes for deep approaches to learning. British Journal of Educational Technology, 42(2), 233-250. https://doi.org/10.1111/j.1467-8535.2009.01029.x.

All, A., Castellar, E. N. P., \& Looy, J. Van. (2021). Digital Game-Based Learning effectiveness assessment: Reflections on study design. Computers \& Education, 167. https://doi.org/10.1016/j.compedu.2021.104160.

Anitha Kumari, T., Hemalatha, C. H., Subhani Ali, M., \& Naresh, R. (2020). Survey on impact and learning's of the online courses on the present era. Procedia Computer Science, 172, 82-91. https://doi.org/10.1016/j.procs.2020.05.167.

Bartel, A., \& Hagel, G. (2014). Engaging students with a mobile game-based learning system in university education. International Journal of Interactive Mobile Technologies, 8(4), 957- 960. https://doi.org/10.3991/ijim.v8i4.3991.

Binali, T., Tsai, C.-C., \& Chang, H.-Y. (2021). University students' profiles of online learning and their relation to online metacognitive regulation and internet-specific epistemic justification. Computers \& Education, 175. https://doi.org/10.1016/j.compedu.2021.104315.

Buchori, Rahmawati, S., \& Wardani, S. (2017). The Development of A Learning Media for Visualizing the Pancasila Values Based on Information and Communication Technology. Jurnal Cakrawala Pendidikan, 36(3), 502-521. https://doi.org/10.21831/cp.v36i3.12748.

Chen, E., \& Li, Z. (2011). On the application of multimedia technology in foreign language teaching and learning in China's colleges: Challenges, problems and implications. 2011 International Conference on Multimedia Technology, ICMT 2011, 595-597. https://doi.org/10.1109/ICMT.2011.6001903.

Chen, Y.-L., \& Hsu, C.-C. (2020). Self-regulated mobile game-based English learning in a virtual reality environmen. Computers \& Education, 154. https://doi.org/10.1016/j.compedu.2020.103910.

Cintya, H. B., Mansoor, A. Z., \& Ahmad, H. A. (2021). Cells at Work: Media Integration Mapping. Ultimart : Jurnal Komunikasi Visual, 1. https://doi.org/10.31937/ultimart.v14i1.2000.

Constant, T., \& Levieux, G. (2019). Dynamic Difficulty Adjustment Impact on Players'Confidence. Glasglow: DL ACM, 1. https://doi.org/10.1145/3290605.3300693.

Dinayusadewi, N. P., Ngurah, G., \& Agustika, S. (2020). Development Of Augmented Reality Application As A Mathematics Learning Media In Elementary School Geometry Materials. Journal of Education Technology, 4(2), 204-210. https://doi.org/10.23887/jet.v4i2.25372.

Elianta, P., Prestiliano, J., \& Setiawan, T. A. (2018). Perancangan Board Game sebagai Media Pembelajaran Keselamatan Berkendara untuk Remaja dengan Mekanik Dice Rolling. International Journal of Natural Science and Engineering, 2(3). https://doi.org/10.23887/ijnse.v2i3.17186.

Emerson, A., Cloude, E. B., Azevedo, R., \& Lester, J. (2020). Multimodal learning analytics for game-based learning. British Journal of Educational Technology, 51(5). https://doi.org/10.1111/bjet.12992.

Giannakoulas, A., \& Xinogalos, S. (2018). A pilot study on the effectiveness and acceptance. Education and Information Technologies, 1(2). https://doi.org/10.1007/s10639-018-9702-X.

Greipl, S., Moeller, K., \& Ninaus, M. (2020). Potential and limits of game-based learning. International Journal of Technology Enhanced Learning, 12(4). https://doi.org/10.1504/IJTEL.2020.110047.

Gustiana, A. D., \& Puspita, R. D. (2020). The Effect of Educative Games on the Physical Fitness of Kindergarten Children. Jurnal Pendidikan Jasmani Dan Olahraga, 5(2). https://doi.org/10.17509/jpjo.v5i2.24518.

Herdiansyah, H., Cholily, Y. M., \& Cahyono, H. (2019). The Development of Interactive Instructional Media Using Adobe Flash in a Form of Game on the Geometry Lesson (Cube and Cuboid) for Secondary School. Mathematics Education Journal, 3(1), 32. https://doi.org/10.22219/mej.v3i1.8418.

Hergenrather, M. (2020). Dynamic Difficulty: A Player Perspective. WRIT: Journal of First-Year Writing, 1. https://doi.org/10.25035/writ.03.01.04.

Hermawan, D. P., Herumurti, D., \& Kuswardayan, I. (2017). Efektivitas Penggunaan Game Edukasi Berjenis Puzzle, Rpg Dan Puzzle Rpg Sebagai Sarana Belajar Matematika. JUTI, 15(2). https://doi.org/10.12962/j24068535.v15i2.a663.

Kartika, Y., Wahyuni, R., Sinaga, B., \& Rajaguguk, J. (2018). Improving Math Creative Thinking Ability by using Math Adventure. Journal of Physics: Conference Series, 6(1). https://doi.org/10.1088/17426596/1179/1/012078.

Kido, Y., Tou, N. P., Yanai, N., \& Shimojo, S. (2020). sD\&D: Design and Implementation of Cybersecurity Educational Game with Highly Extensible Functionality. Future of Information and Communication 
Conference, 1. https://doi.org/10.1007/978-3-030-39445-5_62.

Kim, P., Buckner, E., Kim, H., \& Makany, T. (2012). A comparative analysis of a game-based mobile learning model in low-socioeconomic communities of India. International Journal of Educational Development, 3(2). https://doi.org/10.1016/j.ijedudev.2011.05.008.

Kucker, S. C. (2021). Processes and pathways in development via digital media: Examples from word learning. Infant Behavior and Development, 63. https://doi.org/10.1016/j.infbeh.2021.101559.

Kusuma, G. P., Suryapranata, L. K. P., \& Utomo, Y. (2021). Enhancing Historical Learning Using Role-Playing Game on Mobile Platform. Procedia Computer Science, 179. https://doi.org/10.1016/j.procs.2021.01.078.

Lauc, T., Jagodić, G. K., \& Bistrović, J. (2020). Effects of Multimedia Instructional Message on Motivation and Academic Performance of Elementary School Students in Croatia. International Journal of Instruction, 13(4), 491-508. https://doi.org/10.29333/iji.2020.13431a.

Li, F.-Y., Hwang, G.-J., Chen, P.-Y., \& Lin, Y.-J. (2021). Effects of a concept mapping-based two-tier test strategy on students' digital game-based learning performances and behavioral patterns. Computers \& Education, 24. https://doi.org/10.1016/j.compedu.2021.104293.

Mathew, R., Malik, S. I., \& Tawafak, R. M. (2019). Teaching Problem Solving Skills using an Educational Game in a Computer Programming Course. Vilniaus Universiteto Leidykla. https://doi.org/10.15388/infedu.2019.17.

Mufaziah, E., \& Fauziah, P. (2020). Kendala Orang Tua dalam Mendidik Anak Usia Dini pada Saat Pandemi Covid 19. Jurnal Obsesi, 5(2). https://doi.org/10.31004/obsesi.v5i2.746.

Nonthamand, N. (2020). Guideline to develop an instructional design model using video conference in open learning. International Journal of Emerging Technologies in Learning, 15(3), 140-155. https://doi.org/10.3991/ijet.v15i03.10842.

Partovi, T., \& Razavi, M. R. (2019). The effect of game-based learning on academic achievement motivation of elementary school students. Learning and Motivation, 68. https://doi.org/10.1016/j.1mot.2019.101592.

Prasetyo, G., Hidayatullah, M. F., Akhyar, M., Wiranto, \& Perdana, R. (2020). Strengthening Students' Character Through Multimedia Learning In Primary Schools Education: Systematic LiteraturPrasetyo, G., Hidayatullah, M. F., Akhyar, M., Wiranto, \& Perdana, R. (2020). Strengthening Students' Character Through Multimedia Learning In . Humanities \& Social Sciences Reviews, 8(3), 268-277. https://doi.org/10.18510/hssr.2020.8328.

Pratama, L. D., \& Setyaningrum, W. (2018). Game-Based Learning: The effects on student cognitive and affective aspects. Journal of Physics: Conference Series, 1097(1-7). https://doi.org/10.1088/17426596/1097/1/012123.

Rahayuningsih, S. (2020). Animation media of animal husbandry thematic science learning to stimulate scientific attitude in early childhood. International Journal of Scientific and Technology Research. https://doi.org/10.23887/jet.v3i1.17959 Article Metrics.

Rekysika, N. S., \& Haryanto, H. (2019). Media Pembelajaran Ular Tangga Bilangan Untuk Meningkatkan Kemampuan Kognitif Anak Usia 5-6 Tahun. Cakrawala Dini: Jurnal Pendidikan Anak Usia Dini, 10(1), 56-61. https://doi.org/10.17509/cd.v10i1.16000

Rigianti, H. A. (2020). Kendala Pembelajaran Daring Guru Sekolah Dasar Di Banjarnegara. Elementary School: Jurnal Pendidikan Dan Pembelajaran Ke-SD-An, 7(2). https://doi.org/10.31316/esjurnal.v7i2.768.

Saprudin, S., Liliasari, L., Setiawan, A., \& Prihatmanto, A. (2019). The effectiveness of using digital game towards students' academic achievement in small and large classes: A comparative research. International Journal of Learning, Teaching and Educational Research, 18(12), 196-210. https://doi.org/https://doi.org/10.26803/ijlter.18.12.12.

Setiyani, S., Fitriyani, N., \& Sagita, L. (2020). Improving student's mathematical problem solving skills through Quizizz. JRAMathEdu (Journal of Research and Advances in Mathematics Education), 5(3), 276-288. https://doi.org/10.23917/jramathedu.v5i3.10696.

Simbolon, N., \& Satria, A. (2016). Making Ludo Word Game (LWG) to Learn Grammar for Senior High School Students. Inovish Journal, 1(2), 77-85. https://doi.org/10.35314/inovish.v1i2.85.

Su, C.-H., \& Cheng, C.-H. (2013). A Mobile Game-based Insect Learning System for Improving the Learning Achievements. Procedia - Social and Behavioral Sciences, 103. https://doi.org/10.1016/j.sbspro.2013.10.305.

Sun, H., \& Gao, Y. (2016). Impact of an active educational video game on children's motivation, science knowledge, and physical activity. Journal of Sport and Health Science 5, 1(1), 239-245. https://doi.org/10.1016/j.jshs.2014.12.004.

Troussas, C., Krouska, A., \& Sgouropoulou, C. (2020). Collaboration and fuzzy-modeled personalization for mobile game-based learning in higher education. Computers \& Education, 144. https://doi.org/10.1016/j.compedu.2019.103698. 
Van Alten, D. C. D., Phielix, C., Janssen, J., \& Kester, L. (2019). Effects of flipping the classroom on learning outcomes and satisfaction: A meta-analysis. Educational Research Review, 28(June), 1-18. https://doi.org/10.1016/j.edurev.2019.05.003.

Windhiyana, E. (2020). Dampak Covid-19 Terhadap Kegiatan Pembelajaran Online Di Perguruan Tinggi Kristen Di Indonesia. Perspektif Ilmu Pendidikan, 34(1), 1-8. https://doi.org/10.21009/pip.341.1.

Wulandari, R., Susilo, H., \& Kuswandi, D. (2017). Penggunaan Multimedia Interaktif Bermuatan Game Edukasi Untuk Siswa Sekolah Dasar. Jurnal Pendidikan: Teori , Penelitian Dan Pengembangan, 2(8), 10241029. https://doi.org/10.17977/jptpp.v2i8.9759.

Yeh, Y. T., Hung, H. T., \& Hsu, Y. J. (2017). Digital game-based learning for improving students' academic achievement, learning motivation, and willingness to communicate in an english course. International Congress on Advanced Applied Informatics. https://doi.org/10.1109/IIAI-AAI.2017.40.

Yulia, H. (2020). Online Learning to Prevent the Spread of Pandemic Corona Virus in Indonesia. ETERNAL (English Teaching Journal), 11(1). https://doi.org/10.26877/eternal.v11i1.6068.

Yunanto, A. A., Herumurti, D., Rochimah, S., \& Kuswardayan, I. (2019). English Education Game using NonPlayer Character Based on Natural Language Processing. Procedia Computer Science, 1. https://doi.org/10.1016/j.procs.2019.11.158. 